\title{
Enhancing Instructional Delivery in Nigerian Technological Institutions Through the Use of Solar Powered Printing Plate Burner
}

\author{
Otoba Festus, Ph.D \\ Department of Photography, Auchi Polytechnic, Auchi Nigeria
}

\begin{abstract}
The problem of erratic power supply and load shedding of electricity has become a major obstacle preventing educational, industrial and economic development in Nigeria. Despite published efforts of previous and present government to eradicate the scourge, it has refused to go into extinction instead new dimension to the problem keeps unfolding. Consequently, different sectors of the economy that depends on electricity as a source of power supply are either going underground or operating below capacity. The educational sector is not spared from this epidemic; instructional delivery is adversely affected as training equipment that needs electricity to power their electrical motors can only perform below expectation. There is need to think out of the box; joining the global trend to adapt to cleaner and renewable energy. This study examined the use of solar powered printing plate burner in training students of visual art departments in Nigerian tertiary institutions as a means of enhancing instructional delivery. With the tremendous improvement enjoyed as a result of powering printing plate burner with solar energy during training, it was recommended that other training equipment should be fabricated or manufactured to be solar compliant.
\end{abstract}

Keywords: Solar energy, Training equipment, Instructional delivery.

DOI: $10.7176 / J N S R / 11-22-03$

Publication date: November $30^{\text {th }} 2020$

\section{Introduction}

Instructional delivery in Nigerian technological institutions for the past two decades has experienced incessant disruptions as a result of epileptic power supply from the national grid. This situation has become more worrisome as the resuscitation of the ailing economy is partly tied to the revampment of the numerous industries that has gone underground while the few existing ones are operating below capacity. The industry remains the vital domain of the production process and trained skilled manpower, the propelling force to actualize its objectives. The importance of trained, skilled and proficient workforce for the industries cannot be ignored.

The printing plate burner is indispensable equipment in the visual art industries and in the production of goods and services that are utilitarian in nature. Some of these industries include, photography, printing, publishing, graphics communication, advertising to mention but a few. These industries account for greater percentage of the production and supply of photographs and illustrations for diverse publications, notebooks, textbooks, ledger and book-keeping account books, calendars, newspapers, magazines, security items such as currency notes, certificates, postage stamps, cheque books etc, election materials, and other educational and office stationeries that are much needed to oil the wheels of economic growth and sustainable development. According to Plecher (2020), the industry contributed $27.38 \%$ to Nigeria's GDP in 2019 while services contributed $49.73 \%$.

Instructional delivery in Nigerian technological institutions where training of skilled manpower for the above industry occur, has been constantly hampered, disrupted and occasionally cancelled due to erratic power supply. Most equipment used for training students in visual art departments of higher institutions in Nigeria relies heavily on electricity to power their electric motors. Some of these equipment includes the plate burner, enlarger, printing machines, computers, printers, scanners, electric kilns, electric throwing wheels, welding machines, sewing machines, blunger, pug mill, ball mill, etc. Without steady power supply, effective teaching and learning with these equipment becomes a nightmare.

The use of petrol/diesel generators as alternative to power supply from the national grid has been tested and discovered not only to increase the cost of training but also unreliable as constant use of such generators lead to frequent breakdown that disrupts training regularly. It is imperative that technological institutions that utilize electricity to power their training equipment should think out of the box in search of alternative cleaner power source that could guarantee effective teaching and learning. Other sources of power supply include the following:

(a) Hydrogen gas

(b) Tidal energy

(c) Biomass energy

(d) Wind energy

(e) Geothermal energy

(f) Natural gas 
(g) Biofuels

(h) Wave energy

(i) Hydroelectric energy

(j) Nuclear power

(k) Solar energy.

According to Plecher (2020), these alternative power sources have small environmental impact on the earth and their sustainability is reasonably assured.

The choice of alternative energy source to power training equipment in Nigerian tertiary institutions will depend on the comparative advantage of each source, suitability to training equipment and location of institutions across Nigeria. The ultimate purpose is to achieve uninterrupted power supply and join the global movement towards cleaner energy by exiting fossil fuels to renewable energy source. (Aliyu, Ramli\&Saleh, 2013). Nigeria utilizes mainly four different types of energy namly: Natural gas, Oil, Hydro and Coal, while depending heavily on oil as method of electricity production. Nigeria is the seventh largest supplier of oil in the world and is readily available for use as a source for electricity (Ejiogu, 2013). Nigeria also has large natural supply of coal and is cheapest resource to develop into energy plants. The wind energy that is in abundant supply in Nigeria, especially in the Northern part of the country is unreliable for consistent energy supply. Hydro electricity does not seem practicable for constant and regular supply of electricity because of the dependence on the seasons for amount of water supply that can guarantee regular electricity to Nigerians (Ajayi, 2009). Nuclear energy could be viable because of lack of emissions and reliability for constant supply of electricity. Nigeria has easy access to the Uranium which is needed for the plant and could be used to grow the local economy if properly researched and harnessed (Ejiogu, 2013). Coal which is available in large quantity especially in the eastern part of the country is cheap as source of energy for electricity, but "notorious for its pollution characteristics" (Otoba, 2019). The world is trending towards energy production that is against the depletion of the Ozone layer, therefore the choice of energy source for electricity supply should tilt towards cleaner energy for renewable electricity and solar energy is compactable with these characteristics.

\section{Powering Training Equipment With Solar Energy}

The problem of erratic power supply in Nigeria has become so epidemic that most sectors of the economy are not only recording low productivity, but also folding up in large numbers. The cost of fuelling generators as alternative power supply is not only increasing the unit price of end products and causing inflation, but also making production process discouraging for the entrepreneur. The education industry is not left out, most facilities for training students depend on electricity to power the motors of training equipment. Provision of alternative power supply is continuously depleting the lean resources of most tertiary institutions where training and retraining take place. According to Otoba (2019):

One of the most terrifying impediment to the effective teaching and learning of visual arts in tertiary institutions in Nigeria, is the erratic power supply and unprecedented shedding of light meant to power equipment for training students.

He further explained the negative effects of this regrettable state of affairs thus: the quality and standard of instructions given to students are compromised, the reputation of creative art departments is jeopardized, the proficiency of creative art graduates is critically scrutinized by employers, the cost of bequeathing quality instruction to students is skyrocketing beyond roof top, the life of existing instructional equipment is highly endangered, students enrolment into visual art departments is declining beyond comprehension, and the general standard of education is falling by each passing day.

Therefore, the solar energy as an alternative source of power supply to power training equipment in Nigerian tertiary institution is not only renewably clean, but economic and reliable.

The main objective is to employ solar energy in instructional delivery for students of visual and other graphics communication arts in Nigerian tertiary institutions. Specifically it will;

(a) power equipment used as instructional aid for students in Graphics, Printing technology, Textiles and Photography departments.

(b) serve as energy source that relies on the sun and devoid of power outage.

(c) reduce the running cost of training institutions now and on the long run.

The significance of the use of solar energy in instructional delivery is that the cost of fuelling generators as alternative source of power supply will reduce. This will prolong the life span of such generators which can be channeled for use in other ventures.

The training of students can effectively be carried out in the workshops, studios and laboratories without disruption from power outage as sun is an inheritance in Africa.

Training equipment such as plate burner, sewing machines, electric kilns, electric throwing wheels, welding machines etc. can be fabricated to be solar energy compliant. 


\section{Solar Powered Printing Plate Burner:}

The printing plate burner, also called "flip-top Cabinet" is an equipment basically designed to transfer typographic and halftone images in film format onto pre-sensitized printing plate (lithographic plate) for the reproduction of graphic stationeries, such as Textbook, Calendar, Journal, Office file, Headed paper, Bulleting, and so on.

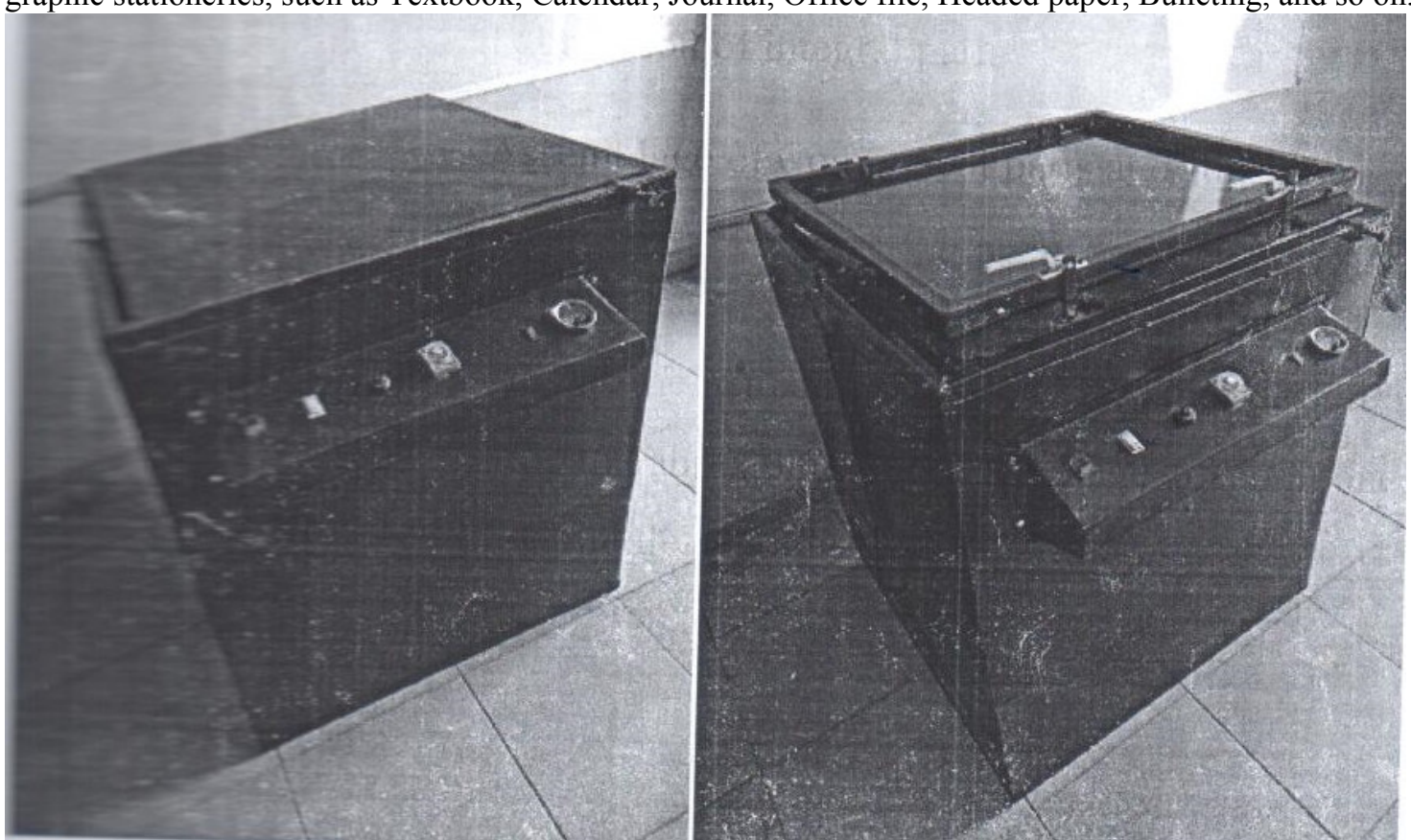

Solar powered printing plate burner fabricated by Otoba, F.O. under the sponsorship of TETFUND, IBR 2014/2015 intervention.

The solar powered printing plate burner comprises of the following components:

a. Top compartment - The top compartment consists of a flip-top diaphragm with transparent glass on one side and a flat metal sheet on the other.

b. Control Panel - This is the control unit of the system. The panel encases the timer, vacuum guage, and control switches.

c. Middle compartment - The middle compartment accommodates the light source and reflector.

d. Lower compartment - Consists of the compressor, choke and other vacuum accessories.

e. Solar accessories- The solar accessories include the Solar panel and stand, Inverter converter panel, Inverter battery, Changeover switch and assorted wires for electrical connections.

Functions of the solar-powered printing plate burner in instructional delivery.

The solar-powered printing plate burner was basically designed for exposing lithographic films onto the offset printing plate. This function is carried out by utilizing the different components of the device. The compressor, incorporated into the machine activates the suction functionality of the device by extracting air from the diaphragm prepared to accommodate both the sheet film and the plate. The diaphragm contains a blanket fitted with suction hole from the compressor and a transparent glass unit that is adjustable. The compressor converts the electrical solar energy into suction system through the coil and mechanical accessories. The airspace in the diaphragm between the blanket and glass is tightly held by the vacuum pump in the compressor, and holds film and plate together and flat to enable image on the film transfer to the plate through exposure from the light source.

The control panel of the equipment contains accessories that provides regulation to the various activities that are carried out using the plate burner. They include:

a. Timer - the timer has a switch synchronized to it, to control the length of time spent on any activity carried out with the plate burner.

b. Vacuum guage/indicator - This guage and the switch controls the duration of vacuuming exercise when working with the device.

c. Switch buttons - Other switches on the equipment include the general system switch, lamp on/off switch etc.

Apart from the above basic function of the plate burner, it has proven to be very useful in the teaching, learning and practice of skills in photography, textile design and other graphics communication activities that utilize electricity.

Contacting - Contacting is a process related to physical close association. The term contact print in photography 
refers to a print made by exposing the printing paper to light through a negative by placing them physically in close contact. The process of contacting can be effectively carried out in the photographic dark room by placing a point bulb over the diaphragm or flat bed of the plate burner. Both the film negative and photographic paper are arranged in close contact on the flat bed. With the transparent glass facing the point bulb hanging over it, the photographic paper can be exposed using the switch of the bulb. The suction facility of the plate burner provides a perfect condition for the photographic paper and the film negative to lie flat on the bed of the equipment. Similarly, contact printing to determine the density of film strips, laser films and other photographic films can also be achieved using the above process. It can also be used for film-film contacting to achieve special creative effects that are used for advertising design and prints. Other uses of the diaphragm of the plate burner include, tracing of illustrations, transfer of motif to sensitive paper and fabric as well as transfer of large format cartographic drawings to sheet films.

\section{Conclusion}

The use of solar powered printing plate burner as an instructional aid for training students of visual and industrial arts in Nigerian tertiary institutions was aimed at solving the problem of inadequate and erratic power supply from the national grid. The solar energy guarantees uninterrupted and effective teaching and learning in studios, workshops and laboratories of training institutions across the country. If all training equipment are fabricated to be solar compliant, there will be uninterrupted training sessions in educational institutions in Nigeria which will ultimately lead to producing competent and skilled manpower that are needed in the resuscitation of the ailing industries and ensuring industrial and economic growth and sustainable development.

\section{Recommendation}

1. In view of the global trend towards eradicating depletion of the ozone layer, training institutions, industries and homes should look towards the solar energy for cleaner, renewable and reliable source of electricity.

2. Training equipment should be modernized to be compatible with solar energy at the point of manufacture.

3. Government should release more grants to researchers to encourage more study on other cleaner and renewable sources of energy for academic, industrial and domestic uses.

4. Training institutions in Nigeria should be adequately equipped with instructional aids and infrastructure that can guarantee robust teaching and learning.

\section{References:}

Ajayi, O. (2009) Assessment of utilization of wind energy resources in Nigeria. Energy policy 39(2). Http//en.m. Wikipedia.org.

Retrieved July 16, 2018.

Aliyu, A.; Ramli, A., \&Saleh, M. (2013). "Nigeria Electricity Crises”: Power generation capacity, expansion and environmental Ramifications.Energy, 61(8). 354 - 367. https://en.

M.wikipedia.org. RetrievedJuly 16, 2018.

Ejiogu, (2013). “Nigeria energy supply crises” Http//en.m.wikipedia.org. Retrieved July 16, 2018.

Otoba, F.O. (2019). Electricity supply demand on the teaching and learning of visual arts in Tertiary Institutions in Nigeria. The pens: An International Journal ofthe African writers. X(VI).

Plecher, H. (2020). Distribution of Gross Domestic Product (GDP) across Economic Sectors in Nigeria.www. statista.com. Retrieved September 3, 2020. 